\title{
PENINGKATAN PRODUKSI DAN KUALITAS TELUR INDUK BANDENG (Chanos chanos) DENGAN PENAMBAHAN BAHAN PENGKAYA PADA PAKAN
}

\author{
Muhammad Marzuqi ${ }^{*}$, Retno Andamari, Ni Wayan Widya Astuti, Wawan Andriyanto, dan \\ Nyoman Adiasmara Giri
}

Balai Besar Riset Budidaya Laut dan Penyuluhan Perikanan

(Naskah diterima: 27 November 2017; Revisi final: 22 Februari 2018; Disetujui publikasi: 22 Februari 2018)

\begin{abstract}
ABSTRAK
Pakan merupakan salah satu faktor yang berpengaruh terhadap performa reproduksi induk ikan bandeng. Ketersediaan pelet komersial yang spesifik untuk pemeliharaan induk bandeng hingga kini belum ada sehingga perlu dilakukan pengembangan pakan untuk menghasilkan performa reproduksi yang lebih baik. Penelitian ini bertujuan untuk meningkatkan produksi dan kualitas telur induk bandeng melalui aplikasi bahan pengkaya pada pakan. Penelitian dilakukan di unit pembenihan skala lengkap Desa Banyupoh dan Desa Sanggalangit, Bali Utara. Jumlah induk yang digunakan adalah 165 ekor yang dipelihara dalam dua buah bak volume $100 \mathrm{~m}^{3}$ (di Desa Banyupoh) dan 100 ekor yang dipelihara dalam dua buah bak volume $100 \mathrm{~m}^{3}$ (di Desa Sanggalangit). Perlakuan yang digunakan adalah pakan komersial dengan penambahan bahan pengkaya (pakan uji) dan tanpa penambahan bahan pengkaya pakan (pakan kontrol). Bahan pengkaya berupa emulsi yang terdiri atas lesitin, minyak cumi, minyak ikan, minyak jagung, vitamin $\mathrm{E}$, dan vitamin C yang dicampur dalam pakan dengan dosis sebesar $120 \mathrm{~g} / \mathrm{kg}$ pakan. Pakan diberikan secara at-satiation dengan frekuensi 2-3 kali sehari. Penelitian berlangsung selama 10 bulan. Parameter yang diamati meliputi frekuensi pemijahan, produksi, dan kualitas telur. Hasil penelitian menunjukkan bahwa penggunaan bahan pengkaya dalam pakan mampu meningkatkan frekuensi pemijahan induk dengan rerata sebanyak lima kali/bulan di unit pembenihan skala lengkap Desa Banyupoh dan empat kali/bulan di unit pembenihan skala lengkap Desa Sanggalangit, serta dapat meningkatkan produksi telur masingmasing sebesar $56 \%$ dan $102 \%$ dibandingkan pakan kontrol. Teknik penambahan bahan pengkaya pada pakan dapat diterapkan pada pemeliharaan induk bandeng untuk mendukung produksi telur dan frekuensi pemijahan yang baik.
\end{abstract}

KATA KUNCI: bahan pengkaya; induk bandeng; pakan; produksi telur

ABSTRACT: Improvement of production and quality of milkfish (Chanos chanos) broodstock eggs through the application of enriched feed formulation. By: Muhammad Marzuqi, Retno Andamari, Ni Wayan Widya Astuti, Wawan Andriyanto, and Nyoman Adiasmara Giri

Feed is one of the factors affecting the reproduction performance of milkfish broodstock. Hatcheries use mostly commercial pellets to feed broodstock despite that it is not a natural feed for milkfish. Thus, thefood has to be enriched to maintain or improve the spawning performance of milkfish broodstock. The purpose of this study was to improve spawning performance of milkfish broodstock through the application of enriched-formulation feed. The study was conducted at two milkfish hatcheries in Banyupoh and Sanggalangit villages, North Bali. The number of broodstock used at Banyupoh village hatchery were 165 ind reared in two $100 \mathrm{~m}^{3}$ concrete tanks. In the hatchery at Sanggalangit Village, 100 fish were reared in two $100 \mathrm{~m}^{3}$ concrete tanks. The feed enrichment formulation used a mixture of lecithin, squid oil, fish oil, corn oil, vitamin E, and vitamin C. The feed enrichment formulation was prepared in emulsion form and mixed with $120 \mathrm{~g} / \mathrm{kg}$ dosage of feed. As a control, thefeed used was without enrichment formulation. The feeding frequency was 2-3 times per day to satiation. The experiment was carried out for 10 months. The parameters observed included egg production, egg quality and spawning frequency. The results showed that the

\footnotetext{
\# Korespondensi: Balai Besar Riset Budidaya Laut dan

Penyuluhan Perikanan. Banjar Gondol Kec. Gerokgak Kab.

Buleleng, Bali 81155, Indonesia.

Tel.: + 6236292278

E-mail: marzuqi_rim@yahoo.co.id
} 
Peningkatan produksi dan kualitastelur induk bandeng ..... (Muhammad Marzuqi)

enriched feed had increased the spawning frequency of broodstock up to five times/month at the hatchery in Banyupoh and four times/month at Sanggalangit hatchery. Egg production also had increased to 56\%(Banyupoh) and 102\% (Sanggalangit) compared to the control feed. This feed enrichment formulation has the potential in broodstock milkfish rearing to improve the egg production and spawning frequency.

\section{KEYWORDS: feed enrichment; egg production; milk fish broodstock}

\section{PENDAHULUAN}

Ikan bandeng merupakan salah satu komoditas unggulan dalam pengembangan budidaya laut di Indo nesia. Bandeng dibudidayakan karena memiliki pangsa pasar yang luas. Selain untuk konsumsi, bandeng juga digunakan sebagai umpan untuk penangkapan tuna. Sebagian besar bandeng dipasarkan dalam bentuk presto, bandeng asap, bandeng tandu (tanpa duri), otak-otak bandeng, dan bandeng crispy. Kebutuhan bandeng terus meningkat seiring dengan peningkatan jumlah penduduk dan makin tingginya kesadaran masyarakat untuk mengonsumsi sumber protein (Mas'ud, 2013).

Indonesia adalah penghasil ikan budidaya terbesar di Asia Tenggara pada tahun 2014, yaitu budidaya bandeng (Chanos chanos) sebesar 4\%dari total produk budidaya yang dihasilkan (SEAFDEC, 2017). Salah satu upaya yang dapat dilakukan untuk meningkatkan hasil produksi benih bandeng adalah memperbaiki kualitas pakan untuk meningkatkan hasil pemijahan, fekunditas, dan tingkat penetasan telur.

Benih bandeng hasil budidaya untuk kegiatan pembesaran terutama di tambak berasal dari unit pembenihan skala rumah tangga yang banyak terdapat di wilayah Kecamatan Gerokgak, Kabupaten Buleleng, Bali. Saat ini permasalahan yang dihadapi adalah menurunnya kualitas benih yang dihasilkan. Selain manajemen pemeliharaan larva, salah satu faktor yang yang menentukan kualitas benih adalah telur. Kualitas dan kuantitas telur yang dihasilkan oleh induk bandeng sangat tergantung dari pakan untuk induk.

Pakan pelet induk bandeng merupakan salah satu komponen yang sangat besar peranannya untuk produksi telur maupun biaya produksi. Penggunaan pakan induk bandeng dengan kandungan protein 26,93\% dan lemak 5,42\% serat kasar 7,38\% dan abu $8,53 \%$ telah banyak digunakan pada kegiatan unit pembenihan skala lengkap untuk memproduksi telur. Beberapa unit pembenihan skala lengkap melaporkan bahwa untuk meningkatkan produksi telur menggunakan bahan pengkaya pada pakan induk dengan dosis penggunaan masih bervariasi seperti minyak cumi 2,00-20,00 mL/kg pakan, vitamin C 0,207,08 g/kg pakan; vitamin E 0,17-7,08 g/kg pakan; vitamin mix 2,08-7,08 g/kg pakan; vitamin B1 33,33 butir/ kg pakan; omega protein 5,00-33,33 mL/kg pakan; madu 6,67-20,00 mL/kg pakan dan telur bebek 0,222,00 butir/kg pakan (Marzuqi et al., 2012; Astuti et al., 2012).

Untuk mendapatkan pakan yang berkualitas di samping kebutuhan makronutrien, maka kebutuhan mikronutrien untuk pematangan gonad dan peningkatan kualitas telur ikan perlu juga dipenuhi. Pakan harus mengandung asam lemak tidak jenuh seperti linoleat dan linolenat, eicosa pentaenoic acid (EPA), dan docosa hexaenoic acid (DHA). Kadar asam lemak ikan sangat dipengaruhi oleh kadar asam lemak pakan yang diberikan sebelum pemijahan. Di samping itu, sumber lemak yang penting dalam pakan adalah (minyak cumi/minyak ikan), fosfolipid, dan minyak jagung. Selain asam lemak, hasil penelitian pada ikan kerapu menunjukkan bahwa fosfolipid/lesitin kedelai dibutuhkan untuk kematangan gonad berkisar antara 3,5\%4,5\%dalam pakan (Rustini, 2001; Giri et al., 2002). Pakan induk yang ditambahkan fosfolipid akan mengakibatkan peningkatan kandungan phosphatidylinositol (PI) dan phosphatidylcholine (PC) dalam telur yang dihasilkan. Kandungan PC meningkat hampir empat kali dibandingkan dengan yang tanpa penambahan fosfolipid (Giri et al., 2002). Penggunaan minyak jagung pada pematangan gonad ikan zebra (Danio rerio) dibutuhkan kadar 1\%3\% dalam pakan (Utomo et al., 2006).

Di samping kebutuhan nutrien di atas, penambahan vitamin C dan E pada pakan induk sangat penting dalam proses reproduksi ikan bandeng. Beberapa peneliti menyebutkan bahwa vitamin sangat diperlukan ikan terutama sebagai antioksidan yang berperan membantu mengatur fungsi membran folikel telur. Kebutuhan vitamin bervariasi menurut spesies, ukuran, dan umur ikan. Prijono et al. (1994) mendapatkan bahwa penambahan vitamin $\mathrm{E}$ dalam pakan dengan dosis $100-150 \mathrm{mg} / \mathrm{kg}$ induk bandeng lebih cepat memijah dibanding dosis $50 \mathrm{mg} / \mathrm{kg}$ dan tanpa vitamin E. Watanabe (1988) melaporkan bahwa vitamin E dalam pakan dengan dosis $33 \mathrm{mg} / \mathrm{kg}$ telah mampu berperan untuk membantu mempercepat perkembangan gonad induk ikan ayu. Penambahan vitamin C $25 \mathrm{mg} / \mathrm{kg}$ pakan pada induk kerapu sunu juga menunjukkan pertumbuhan, pematangan gonad dan pemijahan yang baik (Prijono et al., 2005). Pada ikan bandeng yang mengonsumsi vitamin C (Ascorbyl magnesium) $1.000 \mathrm{mg} / \mathrm{kg}$ pakan dapat memperbaiki 
penampilan reproduksi dibanding dengan tanpa suplemen vitamin C (Azwar et al., 2001).

Penambahan bahan pengkaya pakan berupa minyak cumi dan minyak ikan dengan perbandingan (2:1) 30 $\mathrm{g} / \mathrm{kg}$ dan minyak jagung $30 \mathrm{~g} / \mathrm{kg}$, fosfolipid $60 \mathrm{~g} / \mathrm{kg}$, vitamin C $50 \mathrm{mg} / \mathrm{kg}$, dan vitamin E $25 \mathrm{mg} / \mathrm{kg}$ mampu meningkatkan produksi telur dan memperbaiki kualitas telur yang dihasilkan oleh induk bandeng (Marzuqi et al., 2015). Hasil penelitian ini perlu diimplementasikan di masyarakat agar teknologi ini dapat diuji kelayakannya, serta segera dapat diadopsi oleh pembudidaya.

Penelitian ini bertujuan untuk mengaplikasikan penambahan bahan pengkaya pada pakan induk bandeng dalam upaya meningkatkan produksi dan kualitas telur pada unit pembenihan skala lengkap ikan bandeng, Chanos chanos.

\section{BAHAN DAN METODE}

Penelitian dilakukan di unit pembenihan skala lengkap di Desa Banyupoh dan Desa Sanggalangit, Bali Utara. Pemilihan lokasi penelitian berdasarkan fasilitas pemeliharaan induk, jumlah bak, dan jumlah induk yang dimiliki, serta manajemen pakan induk. Jumlah induk yang digunakan adalah 165 ekor yang dipelihara dalam dua buah bak bervolume $100 \mathrm{~m}^{3}$ (di Desa Banyupoh) masing-masing sebanyak 90 dan 75 ekor, sedangkan di Desa Sanggalangit digunakan 100 ekor yang dipelihara dalam dua buah bak bervolume $100 \mathrm{~m}^{3}$, masing-masing sebanyak 50 ekor. Masing-masing bak pemeliharaan induk dilengkapi dengan aerasi dan sistem air mengalir dengan pergantian air mencapai 300\%per hari.

Perlakuan yang digunakan adalah pakan komersial dengan penambahan bahan pengkaya dalam bentuk emulsi (pakan uji/PU) dan tanpa penambahan bahan pengkaya (pakan kontrol/PK). Bahan pengkaya terdiri atas minyak cumi, minyak ikan, minyak jagung, lesitin, vitamin E, dan vitamin C. Cara pembuatan bahan pengkaya pakan adalah dengan mencampur minyak cumi, minyak ikan, dan minyak jagung, vitamin $\mathrm{E}$ dengan menggunakan mixer, selanjutnya ditambahkan lesithin dan vitamin C. Bahan pengkaya yang telah tercampur dimasukkan dalam kantong plastik dan dibawa ke lokasi pemeliharaan induk bandeng untuk dicampurkan dengan pakan komersial sebagai pakan uji. Pakan uji yang telah dicampur bahan pengkaya disimpan di tempat yang sejuk dan memiliki sirkulasi udara yang baik. Dosis bahan pengkaya pakan dibuat berdasarkan penelitian Marzuqi et al. (2015). Dosis bahan pengkaya pakan yang digunakan disajikan pada Tabel 1.
Hasil analisis proksimat pakan buatan dengan penambahan bahan pengkaya dan pakan kontrol untuk induk bandeng di unit pembenihan skala lengkap di Desa Banyupoh dan Desa Sanggalangit dapat dilihat pada Tabel 2.

Pakan diberikan secara at-satiation dengan frekuensi 2-3 kali sehari. Penyiponan kotoran yang mengendap pada bak pemeliharaan induk dilakukan setiap 5-10 hari sekali untuk membersihkan dasar bak.

Pada saat ikan memijah, telur tertampung di tempat pengumpul telur (egg collector) yang dipasang pada pipa pembuangan bagian atas bak. Pemanenan telur dilakukan sekitar pukul 04.00-07.00 dengan menggunakan saringan telur (scoope net), lalu dikumpulkan di sebuah ember volume 30 liter. Telur dibersihkan menggunakan saringan kasar untuk memisahkan antara kotoran dengan telur. Telur yang telah bersih diinkubasi di dalam akuarium bervolume 100 liter. Pada saat inkubasi, telur yang dibuahi (fertile) akan mengapung di permukaan air dan telur yang tidak dibuahi (unfertile) akan mengendap apabila aerasi diangkat. Telur yang tidak dibuahi kemudian dibuang melalui penyiponan dan telur yang dibuahi dihitung jumlahnya. Parameter yang diamati berupa frekuensi pemijahan, produksi telur dan kualitas telur (fertilitas dan derajat penetasan).

Semua data yang diperoleh disajikan secara deskriptif. Data tersebut digunakan sebagai bahan evaluasi untuk mengetahui pengaruh aplikasi bahan pengkaya pada pakan di unit pembenihan skala lengkap ikan bandeng.

\section{HASIL DAN BAHASAN}

Hasil produksi telur ikan bandeng di Desa Banyupoh dengan menggunakan pakan uji dan pakan kontrol ditampilkan pada Gambar 1. Selama sepuluh bulan pemeliharaan induk bandeng di Desa Banyupoh dengan menggunakan pakan uji, produksi telur tertinggi diperoleh pada bulan September dan Oktober yaitu sebesar 29 juta butir, sedangkan terendah diperoleh pada bulan Juli sebesar 14 juta butir. Pemeliharaan dengan menggunakan pakan kontrol, menghasilkan telur tertinggi pada bulan Oktober sebesar 18 juta butir dan terendah pada bulan Juli sebesar 10 juta butir. Dari data tersebut terlihat bahwa dengan menggunakan pakan uji terjadi peningkatan produksi telur rata rata 21.120.238 butir per bulan. Proporsi antara telur yang dibuahi dan tidak dibuahi juga terlihat dari Gambar 1. Keseluruhan produksi telur (Mei-November) pada induk bandeng yang diberikan pakan uji berjumlah 147.841 .666 butir, terdiri atas 114.621.644 butir dibuahi dan 33.220.022 butir tidak dibuahi. Produksi 
Tabel 1. Komposisi bahan pengkaya pakan induk bandeng

Table 1. Composition of feed enrichment of milkfish broodstock diet

\begin{tabular}{lc}
\hline \multicolumn{1}{c}{ Bahan pengkaya (Enrichment ingredients) } & Jumlah (T otal ) (g/kg) \\
\hline Lesitin (Lecithin) & 60 \\
Minyak cumi (Squid oil) & 20 \\
Minyak ikan (Fish oil ) & 10 \\
Minyak jagung (Corn oil) & 30 \\
Vitamin C & 0.05 \\
Vitamin E & 0.025 \\
\hline
\end{tabular}

Tabel 2. Komposisi proksimat pakan penelitian (bobot kering) $(\%$

Table 2. Proximate composition of experimental feeds (dry matter) (\%)

\begin{tabular}{ccccc}
\hline Lokasi (Location) & Pakan (Feed) & Abu (Ash) & Protein & Lemak (Lipid) \\
\hline \multirow{2}{*}{ Banyupoh } & Pakan uji (Test feed) & 10.82 & 42.72 & 20.70 \\
& Pakan kontro|* (Control feed) & 9.38 & 34.79 & 7.75 \\
\hline \multirow{2}{*}{ Sanggalangit } & Pakan uji (Test feed) & 10.83 & 43.28 & 20.37 \\
& Pakan kontro** (Control feed) & 10.01 & 34.29 & 8.46 \\
\hline \multirow{2}{*}{ Keterangan (Note): } & Jenis pakan dan bahan pengkaya sama untuk induk bandeng di Desa Banyupoh dan \\
& Desa Sangalangit (Types of feed and enrichment ingredients were the same given to \\
& the milkfish broodstock at Banyupoh Village and Sanggalangit Village) \\
& *Jenis pakan kontrol untuk induk bandeng di Desa Banyupoh dan Desa \\
& Sangalangit adalah sama, namun dengan jumlah dan jenis bahan pengkaya yang \\
& berbeda (The type of control feed for milkfish broodstock at Banyupoh and \\
& Sanggalangit Village was the same but with different & number and type of \\
& encriched material)
\end{tabular}

telur (Mei-November) pada induk bandeng yang diberikan pakan kontrol berjumlah 95.046 .666 butir, terdiri atas 72.815 .251 butir dibuahi dan 22.231 .415 tidak dibuahi. Proporsi telur yang dibuahi pada induk yang diberikan pakan uji lebih banyak (77,53\%) dibandingkan dengan telur yang dibuahi pada induk yang diberikan pakan kontrol $(76,61 \%$.

Berdasarkan Gambar 1 terlihat bahwa pola produksi telur induk bandeng di Desa Banyupoh, pada bulan Mei hingga Juli induk bandeng tidak produktif memproduksi telur. Produksi telur yang rendah tersebut, diduga karena faktor lingkungan (musim hujan) sehingga suhu air pemeliharaan induk bandeng mengalami penurunan $27,0^{\circ} \mathrm{C}$ pada masing-masing bak pemeliharaan induk bandeng. Namun, setelah bulan Juli, produksi telur meningkat kembali dan mencapai puncaknya pada bulan Oktober, karena suhu air pemeliharaan induk bandeng mengalami peningkatan sekitar $29,7^{\circ} \mathrm{C}$, sehingga dapat mendukung proses pemijahan.

Pola rerata frekuensi pemijahan induk bandeng di Desa Banyupoh disajikan pada Gambar 2.
Berdasarkan Gambar 2 terlihat bahwa induk bandeng yang diberi pakan uji mengalami frekuensi pemijahan yang lebih sering (16 kali) dibandingkan dengan induk bandeng yang diberi pakan kontrol (11 kali). Frekuensi pemijahan paling banyak terjadi pada bulan Oktober yaitu mencapai 20 kali/bulan pada pakan uji. Pada induk yang diberi pakan kontrol terjadi pada bulan September dengan frekuensi sebanyak 14 kali/ bulan seperti tersaji pada Tabel 2. Hasil perhitungan frekuensi pemijahan dapat diartikan bahwa induk yang diberi pakan uji lebih sering memijah sebanyak lima kali setiap bulannya.

Hasil produksi telur dari induk bandeng di Desa Sanggalangit dengan menggunakan pakan uji dan pakan kontrol ditampilkan pada Gambar 3. Produksi telur di unit pembenihan skala lengkap di Desa Sanggalangit dan terlihat bahwa pemberian pakan uji untuk induk bandeng menunjukkan produksi telur tertinggi diperoleh pada bulan September yaitu sebesar 10,5 juta, (7,1 juta dibuahi, dan 3,4 juta tidak dibuahi). Pada bulan yang sama pemberian pakan kontrol untuk induk bandeng menunjukkan produksi telur 7,8 juta butir (5,8 juta dibuahi dan sisanya 2,0 


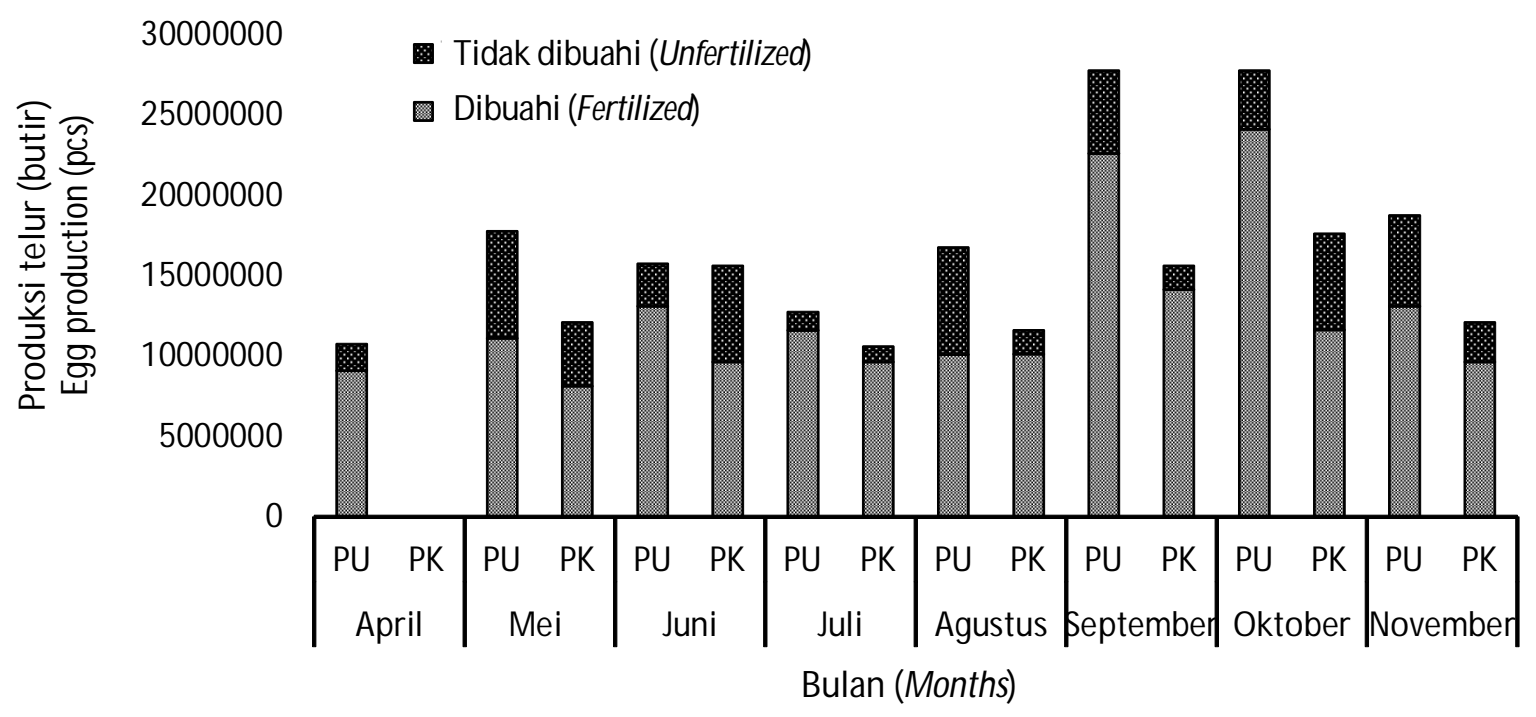

Keterangan (Note): PU = pakan uji (test feed); PK= pakan kontrol (control feed)

Gambar 1. Produksi telur induk bandeng pada unit pembenihan skala lengkap bandeng di Desa Banyupoh.

Figure 1. Egg production of milkfish broodstock in full system hatchery at Banyupoh Village.

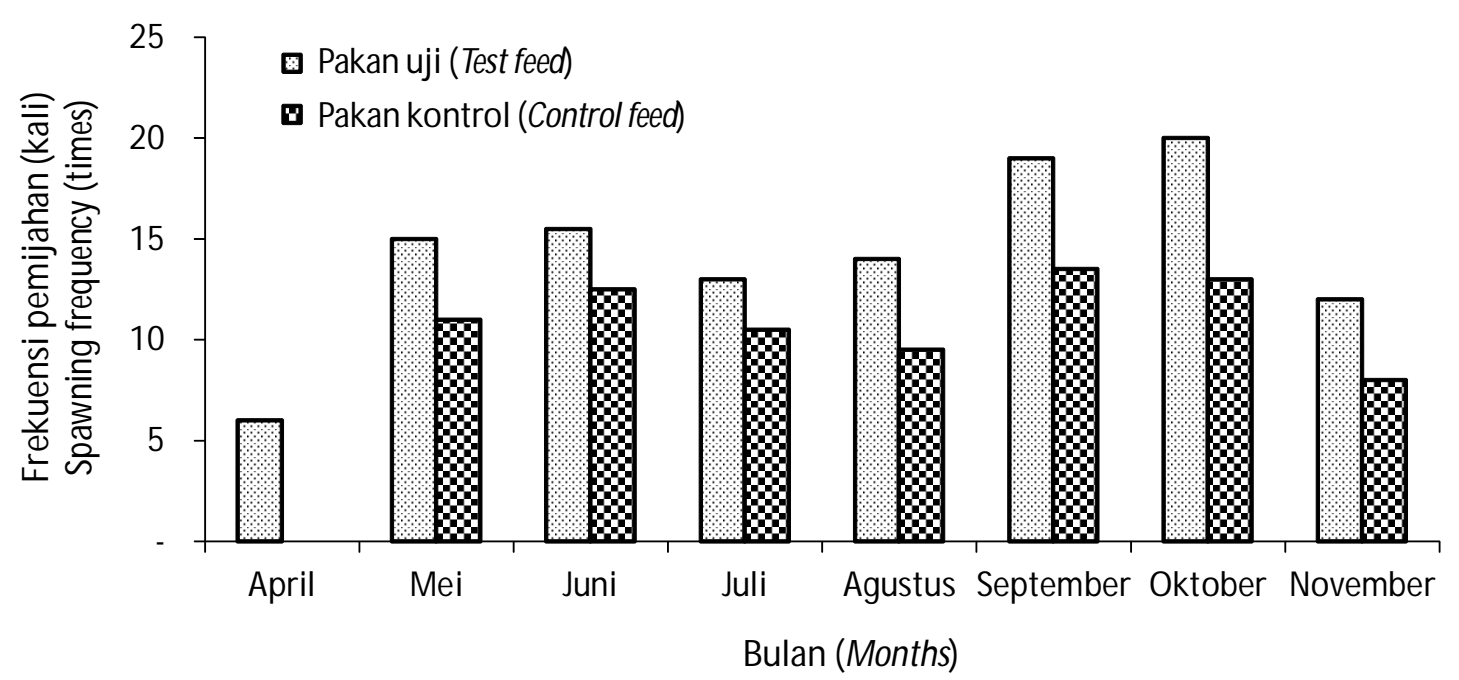

Keterangan (Note): PU = pakan uji (test feed); PK= pakan kontrol (control feed)

Gambar 2. Rerata frekuensi pemijahan induk bandeng pada unit pembenihan skala lengkap di Desa Banyupoh.

Figure 2. Average spawning frequency of milkfish broodstock in full system hatchery at Banyupoh Village.

juta tidak dibuahi). Proporsi telur yang dibuahi lebih banyak $(78,04 \%$ pada induk bandeng yang diberikan pakan uji dibandingkan dengan induk yang diberikan pakan kontrol $(72,06 \%$. Dari data tersebut juga terlihat bahwa dengan menggunakan pakan uji terjadi produksi telur rata-rata 7.654 .530 butir per bulan, sedangkan penggunaan pakan kontrol produksi telur rata-rata hanya 4.050 .771 butir.
Berdasarkan Gambar 3, menunjukkan bahwa pola pemijahan induk bandeng di unit pembenihan skala lengkap Desa Sanggalangit tidak menunjukkan pola khusus. Hal tersebut sesuai dengan Bone \& Moore (2007) yang menyatakan bahwa pada daerah tropis, pemijahan terjadi sepanjang tahun, sedangkan ikan di daerah beriklim subtropis, pemijahan terjadi musiman, khususnya pada musim semi. Produksi telur 


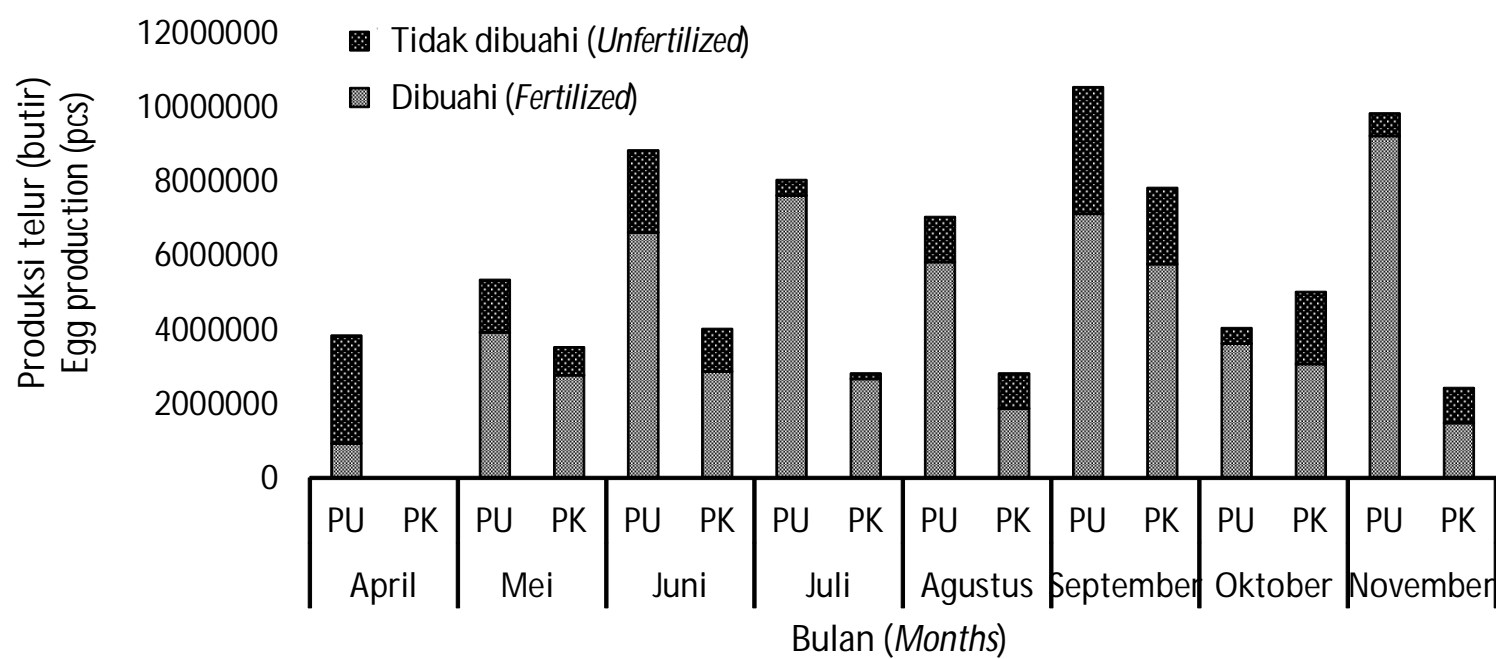

Keterangan (Note): PU = pakan uji (test feed); PK = pakan kontrol (control feed)

Gambar 3. Produksi telur induk bandeng pada unit pembenihan skala lengkap di Desa Sanggalangit.

Figure 3. Eggs production of milkfish broodstock in full system hatchery at Sanggalangit Village.

paling rendah dari induk bandeng terjadi pada bulan Okto ber. Induk bandeng yang diberikan pakan uji hanya bertelur 4.025 .959 butir, sedangkan yang diberi pakan kontrol 5.007.914 butir. Hal tersebut diduga karena rendahnya kualitas lingkungan air laut di Wilayah Sanggalangit. Pemijahan pada ikan secara umum dipengaruhi oleh suhu dan kualitas air (Davidson, 2015). Kualitas air meliputi kandungan nitrat, nitrogen, salinitas, dan senyawa yang memengaruhi pematangan gonad. Pada bulan Mei dan bulan Juni terjadi peningkatan produksi telur, kemudian terjadi penurunan produksi telur pada bulan Juli. Setelah bulan Juli, produksi telur akan meningkat kembali dan mencapai puncaknya pada bulan September.

Rerata frekuensi pemijahan induk bandeng di Desa Sanggalangit disajikan pada Gambar 4.

Berdasarkan Gambar 4 terlihat bahwa induk bandeng yang diberi pakan uji mengalami frekuensi pemijahan yang lebih sering bila dibandingkan dengan induk bandeng yang diberi pakan kontrol. Frekuensi pemijahan paling banyak terjadi pada bulan September yaitu mencapai 11 kali/bulan pada pakan uji. Pada induk yang diberi pakan kontrol memiliki frekuensi pemijahan terbanyak sebesar 5 kali/bulan. Hal ini menunjukkan bahwa induk bandeng yang diberi pakan uji lebih sering memijah sebanyak empat kali setiap bulannya (Tabel 3).

Keragaan kualitas dan jumlah telur di dua lokasi selama penelitian tertera pada Tabel 3.

Pada Tabel 3 menunjukkan bahwa induk bandeng di unit pembenihan skala lengkap Desa Banyupoh yang diberi pakan uji memiliki derajat pembuahan telur relatif lebih tinggi $(77,53 \%$ bila dibandingkan dengan induk yang diberi pakan kontrol $(76,61 \%$. Hal yang sama terlihat pada nilai derajat penetasan telur dan ukuran diameter telur yang dihasilkan. Pada induk bandeng di unit pembenihan skala lengkap Desa Sanggalangit menunjukkan bahwa derajat pembuahan, derajat penetasan, serta diameter telur dari induk yang diberi pakan uji menghasilkan nilai yang lebih tinggi bila dibandingkan dengan induk yang diberi pakan kontrol. Nilai derajat pembuahan, derajat penetasan telur, serta diameter telur yang lebih tinggi ini menunjukkan bahwa terjadi peningkatan kualitas telur. Secara umum, performa hasil peningkatan produksi dan kualitas telur induk bandeng dari unit pembenihan skala lengkap di Desa Banyupoh memiliki performa hasil yang lebih baik dibandingkan dengan di Desa Sanggalangit. Hal ini diduga karena penggunaan umur induk bandeng lebih tua yaitu lima tahun dan kualitas air yg stabil terutama kandungan oksigen air laut. Nilai oksigen yang baik dikarenakan sistem resirkulasi lancar dan optimal pada bak pemeliharaan induk bandeng.

Pada penelitian Woynarovich \& Horvarth dalam Ediwarman (2006) menyatakan bahwa ukuran diameter telur lebih besar dan tersimpannya nutrien pada kuning telur dalam jumlah yang lebih banyak maka akan tersedia energi yang lebih tinggi untuk awal kehidupan embrio, sehingga akan menghasilkan derajat penetasan dan sintasan larva yang lebih tinggi. Menurut Kamler (1992), menyatakan bahwa protein merupakan komponen dominan kuning telur, jumlah, dan komposisinya akan menentukan besar kecilnya ukuran 


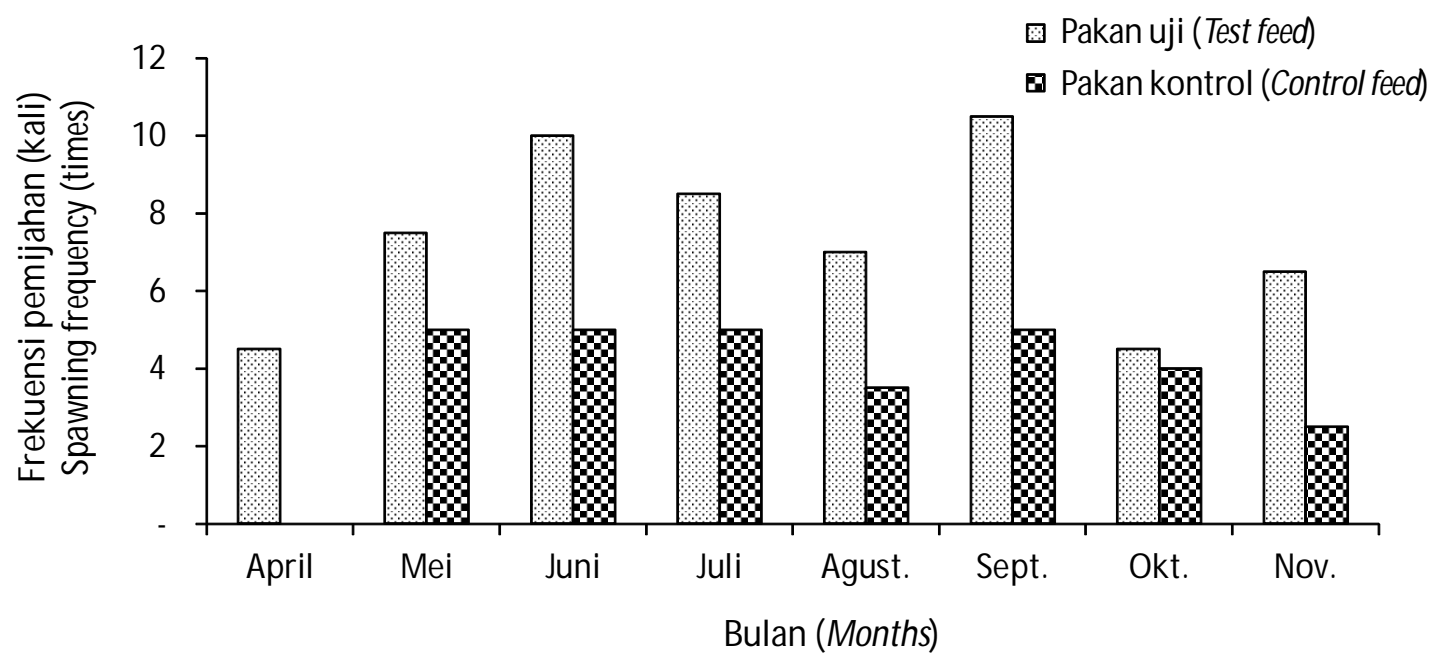

Keterangan (Note): PU= pakan uji (test feed); PK= pakan kontrol (control feed)

Gambar 4. Rerata frekuensi pemijahan induk bandeng pada unit pembenihan skala lengkap di Desa Sanggalangit.

Figure 4. Average spawning frequency of milkfish broodstock in full system hatchery at Sanggalangit Village.

telur, sedangkan komposisi kimia kuning telur bergantung pada status nutrien yang diberikan.

Peningkatan frekuensi pemijahan diduga terjadi karena rematurasi gonad induk bandeng berlangsung lebih cepat. Rematurasi gonad induk bandeng ini berhubungan dengan nutrisi yang terkandung di dalam pakan yang diberikan pada induk bandeng. Proses pembentukan sel telur, penimbunan vitellogenin akan berlangsung dengan optimal dengan tersedianya nutrisi yang cukup untuk reproduksi sehingga produksi telur meningkat dan frekuensi pemijahan juga bertambah.

Protein adalah komponen yang penting dalam reproduksi ikan. Protein merupakan komponen

Tabel 3. Keragaan kualitas dan jumlah telur dari induk bandeng di unit pembenihan skala lengkap Desa Banyupoh dan Desa Sanggalangit, Bali Utara

Table 3. Egg quality and total egg performance of milkfish broodstock in full system hatchery at Banyupoh and Sanggalangit Village, North Bali

\begin{tabular}{|c|c|c|c|c|}
\hline \multirow{2}{*}{$\begin{array}{l}\text { Parameter } \\
\text { Parameters }\end{array}$} & \multicolumn{2}{|c|}{ Banyupoh } & \multicolumn{2}{|c|}{ Sanggalangit } \\
\hline & $\begin{array}{l}\text { Pakan uji/PU } \\
\text { Test feed/PU }\end{array}$ & $\begin{array}{c}\text { Pakan kontrol/PK } \\
\text { Control feed/PK }\end{array}$ & $\begin{array}{l}\text { Pakan uji/PU } \\
\text { Test feed/PU }\end{array}$ & $\begin{array}{c}\text { Pakan kontrol/PK } \\
\text { Control feed/PK }\end{array}$ \\
\hline $\begin{array}{l}\text { Jumlah induk (ekor/bak) } \\
\text { Number of broodstock (fish/tank) }\end{array}$ & 95 & 70 & 50 & 50 \\
\hline $\begin{array}{l}\text { Rerata frekuensi pemijahan/bulan (M ei-November) } \\
\text { Average spawning frequency/month (May-November) }\end{array}$ & 16 & 11 & 8 & 4 \\
\hline $\begin{array}{l}\text { Derajat pembuahan } \\
\text { Fertilization rate }(\%)\end{array}$ & 77.53 & 76.61 & 78.04 & 72.06 \\
\hline $\begin{array}{l}\text { Derajat penetasan } \\
\text { Hatching rate }(\%)\end{array}$ & 85.33 & 79.80 & 83,25 & 81.83 \\
\hline $\begin{array}{l}\text { Diameter telur } \\
\text { Egg diameter }(\mathrm{mm})\end{array}$ & 1.22 & 1.21 & 1.19 & 1.16 \\
\hline $\begin{array}{l}\text { Produksi telur (M ei- November)/butir } \\
\text { Egg production (May-November)/butir }\end{array}$ & 147.841 .666 & 95.046 .666 & 57.407 .670 & 28.355 .400 \\
\hline $\begin{array}{l}\text { Peningkatan produksi } \\
\text { Production increment (\%) }\end{array}$ & & 56 & & 102 \\
\hline
\end{tabular}


dominan kuning telur, sedangkan jumlah dan komposisi kuning telur menentukan besar kecilnya ukuran telur, dan ukuran telur merupakan indikator kualitas telur (Kamler, 1992). Lemak yang ditimbun dalam telur berperan sebagai sumber energi, dan pengendali daya apung telur, embrio, dan larva (Kamler, 1992). Lemak adalah nutrien yang penting dalam meningkatkan mutu telur karena asam lemak telur merupakan cadangan makanan dengan konversi energi yang paling tinggi. Lemak dan asam lemak merupakan faktor yang sangat memengaruhi keberhasilan reproduksi dan sintasan larva yang menetas. Lemak berperan penting sebagai sumber energi dan menjaga kestabilan permeabilitas membran (Tocher \& Sargent, 1984). Ikan tidak dapat menyintesis sendiri asam lemak linoleat $(18: 2 n-6)$ dan asam linolenat $(18: 2 n-3)$, sehingga untuk memenuhi kebutuhannya perlu disuplai minyak jagung pada pakan. Kekurangan asam lemak esensial dapat menyebabkan penurunan reproduksi dan laju pertumbuhan ikan (M einelt et al., 1999). Pada beberapa ikan, pemberian HUFA melalui pakan induk dapat meningkatkan fekunditas, derajat pembuahan, dan kualitas telur (Izquierdo et al., 2001). Fekunditas dan derajat penetasan telur ikan Siganus guttatus semakin meningkat seiring dengan peningkatan kadar lemak dari 12\%ke 18\%(Duray dalam Izquierdo et al., 2001). Hasil analisis proksimat pakan uji yang mendapatkan kadar lemak di kedua lokasi berkisar 20,37\% 20,70\% Nilai kadar lemak ini masih kisaran yang dapat mendukung tingkat kematangan gonad induk bandeng.

Peningkatan kadar protein dan kadar lemak pakan induk bandeng akan menyediakan nutrien yang dibutuhkan dalam proses pematangan gonad. Akibatnya induk akan semakin cepat mengalami pematangan gonad, sehingga meningkatkan frekuensi pemijahan. Selain itu, nutrien yang cukup juga akan membuat jumlah telur yang dihasilkan induk menjadi lebih banyak, sehingga produksi telur semakin meningkat.
Hasil pengamatan kualitas air sebagai data dukung pada pemeliharaan induk bandeng dengan pemberian pakan uji dan pakan kontrol disajikan pada Tabel 4.

Kisaran kualitas air selama penelitian relatif hampir sama di kedua lokasi penelitian karena pemasukan air laut menggunakan sistem air mengalir dengan pergantian air sebanyak 300\% /hari. Semua parameter kualitas air yang diamati masih layak untuk pemeliharaan induk ikan bandeng.

\section{KESIMPULAN}

Penggunaan bahan pengkaya pada pakan induk bandeng (Chanos chanos) dapat meningkatkan produksi telur, kualitas telur, frekuensi pemijahan. Rerata frekuensi pemijahan sebanyak lima kali/bulan dan produksi telur meningkat sebesar $56 \%$ di unit pembenihan skala lengkap Desa Banyupoh dan empat kali/bulan, serta produksi telur hanya $102 \%$ di Desa Sanggalangit.

\section{UCAPAN TERIMA KASIH}

Ucapan terima kasih disampaikan kepada teknisi laboratorium nutrisi Bapak Sumardi, Ibu Ni Made Meta Dwiyanti yang telah membantu selama pelaksanaan penelitian ini. Demikian pula kepada Bapak Ketut Seten dan Bapak Toro yang telah menyediakan fasilitas pembenihannya untuk digunakan sebagai tempat berlangsungnya penelitian ini.

\section{DAFTAR ACUAN}

Astuti, N.W.W., Marzuqi, M., \& Suwirya, K. (2012). Penggunaan bahan pengkaya pada pakan induk bandeng untuk menunjang produksi telur. Prosiding Indoaqua-Forum Inovasi Teknologi Akuakultur 2012. Pusat Penelitian dan Pengembangan Perikanan Budidaya. Jakarta, hlm. 455-460.

Azwar, Z.I., Priyono, A., Setadarma, T., \& Sutarmat, T. (2001). Pengaruh askorbil fosfat magnesium sebagai sumber vitamin $\mathrm{C}$ dalam ransum terhadap

Tabel 4. Analisis kualitas air pada pemeliharaan induk bandeng di unit pembenihan skala lengkap Desa Banyupoh dan Desa Sanggalangit, Bali Utara

Table 4. Water quality analysis of milkfish broodstock reared in full system hatchery at Banyupoh and Sanggalangit Village, North Bali

\begin{tabular}{lcc}
\hline \multirow{1}{*}{$\begin{array}{c}\text { Parameter } \\
\text { Paremeters }\end{array}$} & \multicolumn{2}{c}{$\begin{array}{c}\text { Pembenihan skala lengkap } \\
\text { Full system hatchery }\end{array}$} \\
\cline { 2 - 3 } & $\begin{array}{c}\text { Desa Banyupoh } \\
\text { Banyupoh Village }\end{array}$ & $\begin{array}{c}\text { Desa Sanggalangit } \\
\text { Sanggalangit Village }\end{array}$ \\
\hline Suhu (Temperature) $\left({ }^{\circ} \mathrm{C}\right)$ & $27.0-29.7$ & $27.2-29.9$ \\
Oksigen terlarut (Dissolved oxygen) $)(\mathrm{mg} / \mathrm{L})$ & $3.0-6.6$ & $3.0-5.7$ \\
Salinitas (Salinity) $(\mathrm{ppt})$ & $33.0-34.0$ & $33.0-35.0$ \\
$\mathrm{pH}$ & $8.5-8.7$ & $8.5-8,7$ \\
\hline
\end{tabular}


perkembangan gonad dan mutu telur ikan bandeng (Chanos-chanos Forsskal). Jurnal Penelitian Perikanan Indonesia, 7(2), 40-47.

Bone, Q., \& Moore, R.H. (2007). Biology of fishes. $3^{\text {rd }}$ Edition. USA: Taylor \& Francis Group.

Davidson, J. (2015). A review of factors influencing maturation of Atlantic salmon (Salmo salar) with focus on water recirculation aquaculture system environments. USA: The Conservation Fund Freshwater Institute.

Ediwarman. (2006). Pengaruh tepung ikan lokal dalam pakan induk terhadap pematangan gonad dan kualitas telur ikan baung (Hemibagrus nemurus Blkr.). Tesis. Sekolah Pascasarjana. Institut Pertanian Bogor.

Giri, N.A., Setiadharma, T., \& Slamet, B. (2002). Peranan fosfolipid dalam pakan pada pemijahan dan peningkatan kualitas ikan kerapu batik (Epinephelus microdon). Laporan Teknis BBPPBL, Gondol, $6 \mathrm{hlm}$.

Izquierdo, M.S., Fernandez-Palacios, H., \& Tacon, A.G.J. (2001). Effect of broodstock nutrition on reproductive performance of fish. Elsevier Science B.V. Aquaculture, 197, 25-42.

Kamler, E. (1992). Early life history of fish. An energetics approach. London: Chapman and Hall, 267 $\mathrm{pp}$.

Marzuqi, M., Astuti, N.W.W., \& Andamari, R. (2012). Status induk ikan bandeng (Chanos chanos sp). Prosiding Indoaqua-Forum Inovasi Teknologi akuakultur 2012. Pusat Penelitian dan Pengembangan Perikanan Budidaya. Jakarta, hlm. 127-131.

Marzuqi, M., Giri, I N.A., Setiadarma, T., Andamari, R., Andriyanto, W., \& Astuti, N.W.W. (2015). Penggunaan pakan prematurasi untuk peningkatan perkembangan gonad pada calon induk ikan bandeng (Chanos chanos Forsskal). Jurnal Riset Akuakultur, 10(4), 519-530.
Mas'ud, F. (2013). Pengembangan budidaya dan teknologi pengolahan ikan bandeng (Chanos chanos Forsskal) di Kabupaten Lamongan guna meningkatkan nilai tambah. Universitas Islam Lamongan, Jurnal IImu Eksakta, 1(2), 35-46.

Meinelt, T., Schulz, C., \& Wirth, M. (1999). The Fatty acid composition of diet influences the quality of fish eggs. J. Appe. Ichtyol, 15, 19-13.

Prijono, A. (1994). Pengaruh penambahan vitamin E dalam pakan untuk pematangan gonad induk bandeng (Chanos chanos). Jurnal Penelitian Budidaya Pantai, 10(3).

Prijono, A., Suwirya, K., Giri, N.A., Slamet, B., \& Marzuqi, M. (2005). Pertumbuhan dan pematangan gonad induk kerapu sunu Plectropomus leopardus dengan penambahan vitamin C pada pakan. Buku Perikanan Berkelanjutan, Pusat Riset Perikanan Budidaya, BRKP, Jakarta.

Rustini, I. (2001). Pengaruh kadar fosfolipid dan lemak yang berbeda dalam pakan terhadap efisiensi pakan dan pertumbuhan juvenil ikan kerapu bebek (Cromileptes altivelis). Skripsi. PS BDP FPIK Institut Pertanian Bogor. Bogor, $44 \mathrm{hlm}$.

SEAFDEC. (2017). Southeast Asian State of Fisheries and Aquaculture 2017. Bangkok: Southeast Asian Fisheries Development Center.

Tocher, D.R., \& Sargent, J.R. (1984). Analyses of Lipid and fatty acids in ripe roes of some Northwest European Marine Fish. Lipids, 19, 492-499.

Utomo, Rosmawati, \& Mokoginta, I. (2006). Pengaruh pemberian kadar asam lemak $n-6$ berbeda pada kadar asam lemak n-3 tetap ( $0 \%$ dalam pakan terhadap penampilan reproduksi ikan zebra, Danio rerio. Jurnal Akuakultur Indonesia, 5(1), 51-56.

Watanabe, T. (1988). Importance of the study of broodstock nutrition for futher development of aquaculture, p. 395-414. In Nutrition and feeding in fish. London: Academic Press. 